INTERNATIONAL JOURNAL OF RESEARCHES IN BIOSCIENCES, AGRICULTURE \& TECHNOLOGY (C) VISHWASHANTI MULTIPURPOSE SOCIETY (Global Peace Multipurpose Society) R. No. MH-659/13(N) www.vmsindia.org

\title{
WATER QUALITY ASSESSMENT OF WELL WATER IN NILDOH VILLAGE, HINGNA REGION (M.S.) INDIA
}

Wadjikar B. and Masram A.

L.A.D. and Smt. R.P. College for Women, Nagpur (M.S) India Email: amg123321@gmail.com

\begin{abstract}
The present investigation was carried out to study the physicochemical parameters of ground water and its suitability for domestic purpose from Nildoh village, MIDC Hingna. The study area is situated between $21.10^{\circ} \mathrm{N} 78.98^{\circ} \mathrm{E}$ and $9 \mathrm{~km}$ west of Nagpur city. Samples were collected from ground water resource i.e. Dug wells from three different locations and in different seasons during the year 20142015.The parameters studied were pH, Electrical conductance, Turbidity, Total Dissolved solids, Total Hardness, Magnesium, Total Alkalinity, Chloride, Sulphate, Fluoride, Iron. Most of the physicochemical characters were within ISI permissible limit except the high concentration of Total Dissolved Solids and Total Hardness of water which loses its potability and reduces the solubility of oxygen in water. Measures to be taken in terms of groundwater quality management are required.
\end{abstract}

Keywords: Physicochemical parameters, Ground water, ISI, Nildoh

\section{Introduction:}

The drinking water of most countries, communities and municipalities is obtained from boreholes (NYSC, 1990/91 report). About $97.2 \%$ of water on earth is salty and only $2.8 \%$ is present of fresh water which about 20\% constitutes groundwater. Groundwater is highly valued because of certain properties not possessed by surface water (Goel, 2000). Peoples around the world have used groundwater as a source of drinking water and even today more than half the world's population depends on groundwater for survival (UNESCO, 1992). Assessment of water quality is very important for knowing the suitability for various purposes (Ramkrishnaiah, et al., 1991). Water Quality Index (WQI) is required as one of most effective way to communicate water quality (Rajankar et al.,2009).

In our country $70 \%$ of the water is seriously polluted and $75 \%$ illness and $80 \%$ of the child mortality is attributed to water pollution (Zoeteman, 1980). The healthy nature of underground water has also altered (Dasgupta and Purohit, 2001). The industrial pollutants associated with organic matter, inorganic dissolved solids and other unwanted chemicals cause serious ground water problems (Tyagi et al., 2000). During the past decade, widespread reports of ground water contamination have increased public concern about drinking water quality (Yanggen and Born, 1990).
The periodic monitoring of groundwater quality is necessary to safeguard its longterm sustainability, and water quality index is an indicator revealing the composite influence of a number of water quality parameter which are significant for specific beneficial uses (Nair et al., 2006). The present study was undertaken to evaluate the quality of well waters in Nildoh Village, MIDC, Hingna of Nagpur City.

Dug well water is used primarily as a source of drinking water by a vast majority of the rural population in India. Particularly in the village Nildoh, MIDC are of Hingna, according to the record of Grampanchayat Nildoh, there are five common dug wells which have been constructed by the Grampanchyat. At present the Grampanchyat Nildoh supplying the Vena river water through the pipe line by Sanyukta Pani Puravatha Yojana to Nildoh and Digdoh villages. But it is not sufficient for the need and hence the people of the village use the dug well water for drinking and other purposes.

In view of the above, the effective maintenance of water quality of local resources monitoring of their quality parameters and their use as supplement to river water may reduce the water crises. Also the information of water quality of Nildoh and other villages of MIDC area of Hingna is scanty. Hence the present work determining suitability of ground water for drinking and other purpose of MIDC area is 
taken up. The present study also strengthens the national and local water quality data base.

Materials and methods: The well water selected for the present study is from Nildoh Village which is situated between $21.10^{\circ} \mathrm{N}$ $78.98^{\circ} \mathrm{E}$ and $9 \mathrm{~km}$ of west of Nagpur City. The population of village is about five hundred. It shares its boundary with the village Digdoh which is adjacent to MIDC area, Hingna (Figure1).

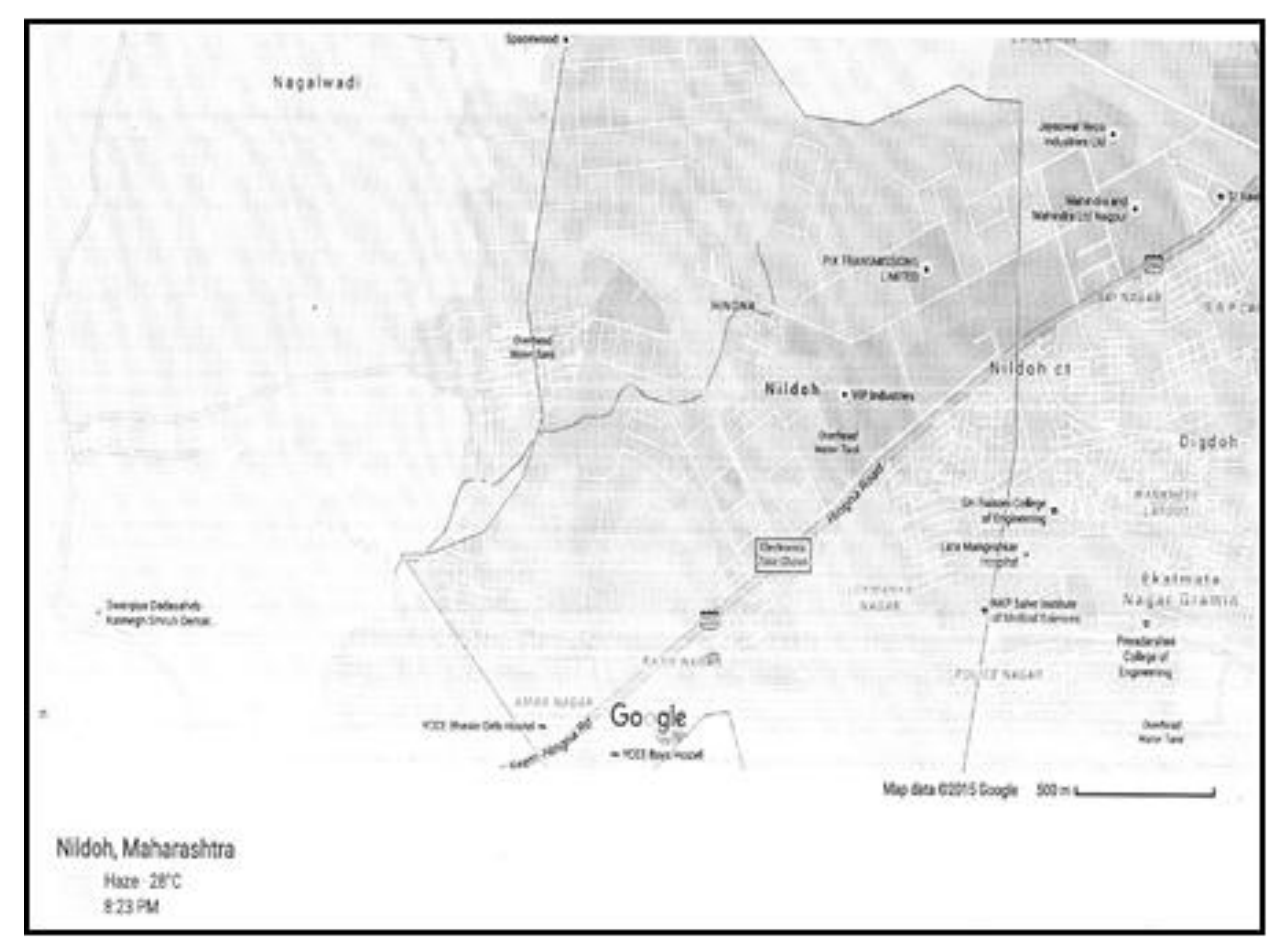

Fig. 1 : Map of Nildoh Village

There are total 5 wells in the village. For the present study three observational well water samples were collected for physicochemical analysis from three different sites of Nildoh Village during the year 2014-2015 samples were collected in sterilized plastic containers (PVC 1000ml). The samples were analysed for physicochemical parameters such as $\mathrm{pH}$, EC, Turbidity, TDS, Total hardnes, Mg, Car, Total Alkalinity, Sulphate, Fluoridc, Iron. The $\mathrm{pH}$ of water was determined by systronies digital $\mathrm{pH}$ meter standardized with buffer tablets. Electrical conductivity (E.C.) was determined by using Elico digital conductometer standardized with $\mathrm{Kcl}$ solution, Total dissolved solids (TDS) was determined by using digital TDS meter standardized with Nacl, Chloride (Cl), Sulphate $\left(\mathrm{SO}_{4}\right)$ were estimated with standared methods prescribed by Goltman et al., (1978), Trivedi and Goel (1986) and APHA (1998).

Results and Discussion: The various physicochemical parameters of the samples collected from Nildoh village were analyzed and the results are tabulated in Table 1. The effect of the various consitutents of water and their range on the potential health of living beings are tabulated in Table 2 . 
Table 1 : Physico-chemical parameters of well water of Nildoh village

\begin{tabular}{|l|c|c|c|c|c|c|c|c|c|}
\hline \multirow{2}{*}{$\begin{array}{c}\text { Physicochemical } \\
\text { Parameters }\end{array}$} & \multicolumn{3}{|c|}{ Site 1 } & \multicolumn{3}{c|}{ Site 2 } & \multicolumn{3}{c|}{ Site 3 } \\
\cline { 2 - 11 } & Monsoon & Winter & Summer & Monsoon & Winter & Summer & Monsoon & Winter & Summer \\
\hline $\mathrm{pH}$ & 7.70 & 7.7 & 7.2 & 7.6 & 7.7 & 7.0 & 7.8 & 7.3 & 7.0 \\
\hline E.C.(ms/cm.) & 2.2 & 2.2 & 2.3 & 1.5 & 1.6 & 1.6 & 2.1 & 2.00 & 2.1 \\
\hline T.D.S. (mg/lit.) & 1132 & 1247 & 1032 & 1200 & 1137 & 1047 & 1250 & 1100 & 1110 \\
\hline Total Hardness & 649 & 650 & 672 & 672 & 666 & 649 & 635 & 640 & 640 \\
\hline Mg(mg/lit.) & 78 & 75 & 75 & 74 & 73 & 78 & 78 & 78 & 78 \\
\hline Total alkalinity) & 278 & 274 & 275 & 270 & 272 & 252 & 259 & 255 & 250 \\
\hline Chloride(mg/lit.) & 195 & 195 & 180 & 190 & 192 & 190 & 197 & 195 & 197 \\
\hline Sulphate(mg/lit.) & 60 & 62 & 63 & 65 & 64 & 65 & 67 & 65 & 67 \\
\hline Fluoride(mg/lit.) & 0.35 & 0.32 & 0.30 & 0.35 & 0.30 & 0.32 & 0.33 & 0.35 & 0.35 \\
\hline Iron(mg/lit.) & 0.16 & 0.9 & 0.10 & 0.12 & 0.13 & 0.10 & 0.12 & 0.10 & 0.10 \\
\hline Turbidity & 1.02 & 1.10 & 1.00 & 1.5 & 1.2 & 1.3 & 1.5 & 1.2 & 1.3 \\
\hline
\end{tabular}

Table 2 : Effect of the various consitutents of water and their range on the potential health of living beings

\begin{tabular}{|c|c|c|}
\hline $\begin{array}{l}\text { Parameters of water } \\
\text { analysis }\end{array}$ & $\begin{array}{l}\text { BIS guideline values } \\
\text { (Max. Allowable) }\end{array}$ & Potential health effects \\
\hline $\mathrm{pH}$ & $6.5-8.5$ & Affects mucous membrane; bitter taste; corrosion \\
\hline Total Alkalinity & $600 \mathrm{mg} / 1$ & Boiled rice turns yellowish \\
\hline Total Hardness & $600 \mathrm{mg} / 1$ & $\begin{array}{l}\text { Poor lathering with soap; deterioration of the quality of clothes; } \\
\text { scale forming }\end{array}$ \\
\hline Chloride & $1000 \mathrm{mg} / 1$ & Taste affected; corrosion \\
\hline Sulphate & $400 \mathrm{mg} / 1$ & Taste affected; gastro-intestinal irritation \\
\hline Fluoride & $1.5 \mathrm{mg} / 1$ & Dental and skeletal fluorosis; non-skeletal manifestations \\
\hline $\begin{array}{l}\text { Total Dissolved } \\
\text { Solids }\end{array}$ & 200mg/1 & $\begin{array}{l}\text { Undesirable taste; gastro-intestinal irritation; corrosion or } \\
\text { incrustation }\end{array}$ \\
\hline
\end{tabular}

\section{pH :}

The seasonal variations of physicochemical characteries of dug well are tabulated in the above table for Mansoon, Winter and Summer seasons. $\mathrm{pH}$ is most important in determining the corrosive nature of water. Lower the $\mathrm{pH}$ value higher is the corrosive nature of water (Gupta et al.,2009). The normal range of $\mathrm{pH}$ in well water was between 6.5 and 8.5 (BIS, 2010) and EPA (2009) recommends this range of $\mathrm{pH}$ as a good guide for indivdual well owners. In the present study the values of $\mathrm{pH}$ of well water were in the range of 7.0 to 7.8 The least value was recorded to be 7.0 at the site- 2 in the summer season while maximum value was recorded to be 7.8 at the site- 3 in rainy season. The reason fot the increase in $\mathrm{pH}$ range may be due to mixing up of the alkaline chemicals, soap and detergents etc. Produced due to industrial and residential activities (Radhakrishanan et al.,2007). Our values was positively correlated by the $\mathrm{pH}$ of ground water in municipal area of Bijapur (Hiremath, 2011) and dug wells of the Digodh village (Masram, 2014) on an average $\mathrm{pH}$ of all samples was in desirable limit as precribed for drinking water standerd. This shows that $\mathrm{pH}$ of water sample was slightly alkaline might be due to high temprature that reduces the solibility of carbondioxide.

\section{Total suspended solids :}

The total suspended solids are composed of carbonates, bicarbonates, chlorides, phosphates and nitrates of calcium, 
magnesium, sodium, potassium, manganese, organic matter, salt and other particles. The total suspended solids of dug well water was minimum $1.00 \mathrm{mg} /$ lit in site1 in summer and maximum $1.5 \mathrm{mg} /$ lit in site- 2 and site- 3 in monsoon. The effect of presence of total suspended solids is the turbidity due to slit and organic matter. The higher the concentration of total suspended solid in scp is an index that it is more polluted ( mahananda et al.,2010). Higher in monsoon compared to winter and summer season, it is evident that the discharge variations are commensurate with weather condition and seasonal variations. High turbidity in wells could be because of soil disturbance and resuspension within the well during water withdrawl. High turbidity can stimulate the bacterial growth, which indicates problems with treatment processes (WHO,2004).

Electrical conductance (E.C.) :

The Electrical Conductance was recorded in the range of 1.5 to $2.2 \mathrm{~ms} / \mathrm{cm}$. for all the samples from all the sites. There are no prescribed standred suggested by ISI for parameter Electrical Conductance for drinking purpose. So no comparison can be made from observed value. No significant variation of conductance was recorded in all seasons.

\section{Total dissolved solids :}

TDS of well water ranged from 1032 to 1250 mg/liter. TDS was minimum 1032 mg/lit. site -1 in summer season and maximum $1250 \mathrm{mg} / \mathrm{lit}$. in siter -3 in monsoon. TDS is a measure of the combined content of all inorganic and organic substances contained in a liquid in moleculer, ionized or micro granular suspended form. The permistible limit of drinking water is $500 \mathrm{mg} / \mathrm{lit}$. (WHO,2004). A high value of TDS reduces water quality for drinking; irrigagation and agriculture purposes (WHO, 1996). The higher TDS in well sources may be attributed to the percolation of effluents into these aquifers from various automobile and small scale industries located in the study area. TDS is a measure of the combined content of all inorganic and organic substances contained in a liquid in a molecular, ionized or microgranular suspended form. The permissible limit of drinking water is $500 \mathrm{mg} / \mathrm{lit}$. (WHO 2004). These results were positively correlated with the pitamahal dam reservoir water in summer, winter and rainy season (patel 1999). According to Trivedy and Goel (1984) an excess amount of TDS in water tends to disturb the ecological balance due to suffocation in aquatic fauna even in the presence of fair amount of dissolved oxygen.

\section{Total hardness :}

It is an indicator of hydrogeology and aesthetic quality of water.Total hardness was found in the sample water ranges from 635 to $672 \mathrm{mg} /$ liter which shows that water is not safe for drinking purpose. The minimum value of total hardness was found to be $635 \mathrm{mg} /$ lit. in site- 3 in monsoon and maximum $672 \mathrm{mg} /$ lit in site-1 in summer and site- 2 in monsoon. However, maximum permissible level prescribed by WHO for drinking water is $500 \mathrm{mg} /$ liter. These results are correlated with the total hardness of the water samples collected from Ambatlur industrial area, Tamilnadu, India (Saravanakumar et al., 2011). The high level of total hardness is due to presence of high concentration of carbonates and bicarbonates. Similar results were also observed by lendhe and yeragi (2004). Water total hardness is imparted mainly by the calcium and magnesium ions, which apart from sulphate, chloride and nitrates are found in combination with carbonates. The permanent hardness is mainly caused by chlorides and sulphates (Roy and kumar 2002). Meshram (2005) reported that calcium hardness is essential for normal growth and development for many aquatic ecosystems.

\section{Total alkalinity :}

Alkalinity of a water in terms of caco3 varied from 250 to $278 \mathrm{mg} /$ lit.

The permissible limit of alkaliity in the water sample is $600 \mathrm{mg} / \mathrm{lit}$ (ISI). In the present investigation it was found to be minimum $250 \mathrm{mg} / \mathrm{lit}$. in site-3 in summer season while maximum $278 \mathrm{mg} / \mathrm{lit}$. in site- 1 in monsoon season which were within the permissible level. These results was positively correlated with groundwater sample of Bairagart district, Orrisa (Mahananda et al., 2010). This result was positively correlated with borewell water of 
chirala town at prakasam district, which was in the range of 110 to $850 \mathrm{mg} / \mathrm{lit}$. (shrinivasa rao and venkatesswarlu,1999). Greater the total alkalinity may be due to consequent washing of excreta near by well water and wastewater discharge from industries. Decrease in temperature bringing down the rate of decomposition of salts to a minimum there by increase the alkaliniy. Increased alkalinity may be due to increase photosynthetic activity of phytoplankton. The water for domestic use having alkalinity less than $100 \mathrm{mg} / \mathrm{lit}$. is safe.

\section{Chloride :}

Chloride is the indicater of contamination with animal and human waste. Chloride is a common constituent of all natural water and is generally not classified as harmful constituents (Chutia and sarma, 2009). According to WHO, maximum permissible limit for chlorid is $500 \mathrm{mg} /$ liter. The value observed in present study was minimum $180 \mathrm{mg} / \mathrm{lit}$. in site -1 in summer and maximum $197 \mathrm{mg} /$ liter in site-3 in the monsoon. The value observed in the present study is in the range of permissible limit (Ravisankar and Poogothai, 2008). The high concentration of chloride is due to dissolution of salts, soil erosion and discharge effluents into water sources. Chloride increases with the increasing degree of eutrophication.

\section{Fluoride :}

Fluoride is level from 0.7 to $1.2 \mathrm{mg} /$ lit is essential in drinking water (Anon,1977). Fluoride at a lower concentration at an average of $1 \mathrm{mg} /$ lit. is regarded as important constituent of drinking water (WHO, 1972). The minimum value recorded $0.30 \mathrm{mg} / \mathrm{lit}$. in site- 1 in summer and site- 2 in winter season while maximum $0.35 \mathrm{mg} /$ lit. in site1 and site- 2 in monsoon and site- 3 in winter and summer season which are within permisible limit of WHO. High fluoride concentration causes dental fluorosis (Hiremath,2011).

\section{Sulphate :}

Concentration of sulphate ions was minimum 60mg/lit.in site-1 in monsoon and maximum $67 \mathrm{mg} / \mathrm{lit}$. in site-3 in monsoon and summer season. Concentration of sulphate has laxative effect
(Lorraine, 2000) which is enhanced when sulphate is consumed with mangesium. The sulphate values were also found to be within the presmisible limits. Water containing magnerisum sulphate (1000 mg/liter) acts as purgative in human adults (Hiremath et al., 2011).

\section{Magnesium :}

The desirable limit of magnesium in water is $50 \mathrm{mg} /$ liter as per ISI. In the present study the minimum value of magnesium was found to be $73 \mathrm{mg} /$ lit. in site- 2 in winter and maximum $78 \mathrm{mg} / \mathrm{lit}$. in site-1 in monsoon and maximum $78 \mathrm{mg} /$ lit. in site- 2 and site- 3 during all the season were exceeded the desirable limit. This may be due to the proximity of a industrial region. This result was positively correlated with the mg content of the water samples collected from the village of Velsao at Goa, which ranged from 80 to $110 \mathrm{mg} / \mathrm{lit}$. (Subhadradevi et al., 2003). The high concentration of $\mathrm{mg}$ adversely affect domestic use of water.

\section{Iron :}

Iron is common in groundwater and most frequent contaminant. In the present study the minimum value was recorded 0.9 $\mathrm{mg} /$ lit. in site-1 in winter and maximum $0.16 \mathrm{mg} /$ lit. in site- 1 in monsoon in well above the permissible limit $<0.3 \mathrm{ppm}$ for iron). This result is positively correlated with the value of iron concentration of well water quality in Tsunami affected regions of south west coast of kerala, India (Nair et al.,2013). Higher level of iron in groundwater can result in discoloured water and unpleasant metallic taste (Jamir et al.,2011).

\section{Conclusion :}

The present investigation has led us to conclude that the quality of water samples subjected to study was not acceptable for some of the physicochemical parameters such as total dissolved solids and total hardness and other parameters which were analysed were not at the level of pollution for ground water. Therefore the water needs to be treated before using it for domestic purposes including drinking. Drinking contaminated water can expose human body to various water borne diseases hence water treatment and improving quality of water before drinking is required. Based on 
the results of analysis, it is suggested that further detailed investigation of the water purifying methods and other sources of water may be carried out in future.

\section{References :}

Anon (1977) National Interim Primary Drinking water regulations. Environmental Protection Agency, office of water supply EPA-570/9,76-003.

APHA (1998) standard methods for chemical examination of water and waste water, American public health Association 20th edition Washington D.C.

BIS (2010) Drinking water specification (second revision of IS 10500) Bureau of Indian standards, New Delhi.

Chutia J. and Sarma S.(2009) Relative content of chloride and sulphate in drinking water samples in different localities of Dhakuakhana sub division of lakhimpur district of Assam; International journal of chemical sciences7(3); 2087-2095.

Dasgupta , A. and Purohit K.M. (2001) status of the surface water quality of mandiakudar. Pollut. Res.20(1), 103-110.

EPA (2009) Drinking water contaminants. National Primary Drinking water regulations. United states Environmental protection Agency publication, 237.

Goel P.K. (2000) water pollution causes, Effects and control, New Age Int.(P) Ltd. New Delhi.

Goltman H.Z., Clymo R.S. and Ohnstad M.A.M. (1978) Methods for physical and chemical analysis of fresh water, I.B.P.H. and Book No. 8, 2nd edition Black well scientific, Oxford.

Gupta D.P., Sunita and Saharan J.P. (2009) Physicochemical analysis of groundwater of selected area of kaithal city (Haryana ) India. Researcher.1(2), 1-5.

Hiremath S.C., Yadawe M.S., Pujeri U.S., Hiremath D.M. Pujar A.S.(2011) Physicochemical analysis of ground water in municipal area of Bijapur (Karnataka), Current World Science; 6(2); 265-269.

Jamir T.T., Devi W.B., Singh U.I. and Singh R.K.B.(2011) Lead, Iron and Manganese contamination in spring pond and well water in Nagaland, one of the seven North -Eastern states of India, A future danger .J.chem.pharma . Res. 3,403411.

Lendhe R.S. and Yeragi S.G. (2004) Physicochemical parameters and zooplankton diversity of phirange kharbhav lake district Thane, M.S.J.Aqua.Biol.19(1) 49-52.

Lorraine C.B. (2000) Assessing the acute gastro intestinal effects of ingesting naturally occurring high level of sulphate in drinking water.

Crit.Rev.clin.Lab.Sci.;37,389-400.

Mahananda M.R.,Mohanty V.R. and Behra N. (2010) physicochemical analysis of surface and ground water of Bargarh district, Orissa India, Int.J.Res.Revi. App.Sci., 2,284-295.

Masram A.S. (2014): Seasonal analysis of physicochemical characteristics of well water in rural area of Digdoh, Hingna, (M.S.) India. J. Researchers in Biosciences, Agriculture and Technology ISSN No. (Online) 2347-517X, Dec. special issue, 4956.

Meshram C.B. (2005) Zooplankton biodiversity in relation to pollution of lake wadali, Amravati. J. Ecotoxicol. Environ Monit, 15,55-59.

Nair G.A.,Bohjuari J.A.,AL-Mariami M.A.,Attia F.A. and El-Toumi F.F. (2006) Grond water quality of North east Libya.J. Env. Biol.,27,695-700.

NYSC (National youth service corp.) Handbook (1990/91) Borno state 1990/91 service year.

Patel R.K.(1999) Assessment of water quality of pitamahal dam.Ind.J.Environ.Protec., 19 (6),437-439.

Pavendan P.,Anbuselvan S. And Sebastian C., Rajasekaran (2011) European Journal of Experimental Biology 1(1): 183-189.

Radhakrishnan R., Dharmaraj K., Ranjithakumari B.D. (2007) A comparative study on the physicochemical and bacterial analysis of drinking, borewell and sewage water in the three different places of sivakasi, Journal of Environmental Biology, 28(1), 105-108

Rajankar P.N.,Gulhane S.R., Tambekar D.H.,Ramteke D.S. and Wate S.R. (2009) water quality assessment of groundwater resources in Nagpur region (India) based on WQI ,Journal of Chemistry,6(3),905-908.

Ramkrishnaiah $\mathbf{S}$ and sri.y. Babu Rao(1991) Environmental and water quality studies in AP state - A case study.

Ravisankar N. And Poogothai S.(2008) A study of groundwater quality in Tsunami affected areas of sirkazhi Taluk, Nagapattinam district, Tamilnadu, India .Sci.Tsun Haz.27;47-55.

Roy Y. And Kumar R. A. (2002), A study of water quality of the rivers of Ranchi district. Ind. J. Environ. Protec. 21 (5), 398-402.

Saravanakumar $K$. and Ranjitkumar R.(2011) Analysis of water quality parameters of groundwater near Ambattur industrial area, Tamilnadu, India. Indian 
Journal of Science and Technology Vol.4,No.5,660-662.

Shrinivasa, Rao B. And Venkatesswarlu P.(1999) Evaluation of groundwater quality in chirala town (Prakasam district) Ind. J. Environ.Protec. 20(3)161-164.

Subhadradevi G., Barbuddhe S.B.,Hazel D. And Dolly C.(2003) Physicochemical characteristics of drinking water at Velsco.(Goa). J. Ecotoxical.Environ. Monit., 13 (3),203-209.

Trivedi R.K. and Goel P.K. (1984) Chemical and Biological methods for water pollution studies, Environmental publication ,Karad, India.

Trivedi R.K. and Goel P.K. (1986) Chemical and biological methods for water and soil pollution studies, Environmental publication,India.

Tyagi P. Buddi D. Chowdary R. And Sawhney R. (2000) physicochemical quality of ground water in industrial areas of India. Pollut. Res. 19,443-445.

UNESCO, (1992) Ground water UNESCO Environmental and development briefs no. 2,14 .
WHO (1996) guidelines for drinking water quality ,2nd ed.vol.2.p.132-367.WHO, Geneva, Switzerland.

WHO (2004) guidelines for drinking water quality ,2nd edition.WHO, Geneva,231-233.

WHO (2004) International Standards of drinking water. World Health organization, Geneva, 55-79.

WHO, (1972) Guidelines for drinking water quality.

Yanggen, D.A. and Born S.M.(1990) Protecting ground water quality by managing local land use J.soil water conser.,45(2),207-210.

Zoeteman, B.C.G. (1980) sensory assessment of water quality, Oxford pergaman press, U.K. 